\title{
KONSELING DENGAN PENDEKATAN RATIONAL EMOTIVE BEHAVIOR THERAPY UNTUK MENGATASI KEBIASAAN MEROKOK
}

\author{
Rina Lestari \\ SMA Negeri 7 Kota Pekanbaru \\ email: rinalestarie@gmail.com
}

\begin{abstract}
Smoking is an act of waste and waste on property. The purpose of this study were to described: 1) smoking habits of students before giving Rational Emotive therapy? ; 2) student smoking habits after giving Rational Emotive therapy ?; and 3) the effectiveness of Rational Emotive counseling therapy in reducing students' smoking habits. This research was used pre test \& post test design. The population in this research were all class X students of SMAN 3 Pekanbaru who had smoking habits with totaling 32 students. To determine the sample of this study, the researcher used purposive sampling. Then, through this technique, 5 students were used as the research sample. Besides, the data was analysed by using " $t$ " test. Moreover, the result of this research showed that: 1) before given emotive rational counseling therapy, students smoking habits are in the high category with an average score of 92.6 and an average percentage of $77.167 \%$; 2) after given emotive rational counseling therapy have decreased, students smoking habit are in the medium category with an average score of 66.8 and an average percentage of $55.667 \%$; and 3) there is a significant difference between students' smoking habits before and have been given emotive rational counseling therapy that is equal to 4,691. This means that rational emotive counseling therapy is effective to reduce student smoking habits.
\end{abstract}

Keyword: Counseling, Rational Emotive Behavior Therapy, Smoking 


\section{PENDAHULUAN}

Siswa Sekolah Menengah Atas (SMA) sedang berada pada tahap perkembangan remaja. Remaja merupakan suatu tahapan perkembangan antara masa anak-anak ke tahap masa dewasa yang mengalami perubahan fisik serta perkembangan kognitif dan sosial (Desmita, 2010. p. 189). Umumnya perilaku merokok untuk pertama kali biasanya dimulai pada saat usia remaja. Masa remaja masa di mana individu mengenal apasaja yang belum ia ketahui baik itu yang positif atau negatif.

Allah SW'T berfirman:

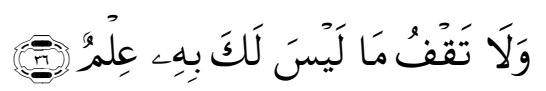

"Dan janganlab kamu mengikuti apa yang kamu tidak mempunyai pengetabuan tentangnya." (Q.S. AlIsraa' 36)

Ayat ini menjelaskan bahwa jika seseorang tidak mengetahui apa yang terkandung dari rokok bahkan faktor yang akan timbul maka janganlah mendekatkan diri dengan barang itu.

Bagi remaja saat ini, merokok merupakan suatu pemandangan yang sangat tidak asing. Kebiasaan merokok dianggap dapat memberikan kenikmatan bagi perokok, namun di lain pihak dapat menimbulkan dampak buruk bagi perokok itu sendiri maupun orang-orang di sekitarnya.

Menurut World Health Organization (WHO), kebiasaan merokok telah terbukti menimbulkan 25 jenis penyakit pada berbagai organ tubuh, seperti penyakit jantung koroner, kanker paru-paru, bronkitis kronis, emfisema, penyakit pembuluh darah, perdarahan pembuluh darah otak, sampai kelainan kehamilan serta janin yang dikandung oleh ibu yang merokok. Dari sejumlah penyakit itu, kematian terbesar perokok disebabkan oleh kanker paru dan bronkitis. Kebiasaan merokok pun merupakan penyebab kematian 10\% penduduk dunia (Saktyowati, 2008, p. 13).

Allah SW'T berfirman:

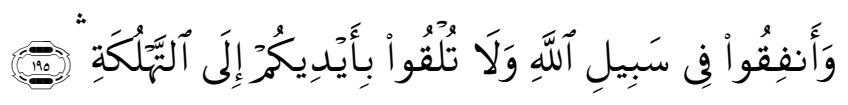

\footnotetext{
"Dan belanjakanlah (barta bendamu) di jalan Allah, dan janganlah kamu menjatubkan dirimu sendiri ke dalam kebinasaan.” (Q.S. Al-Baqarah 195)
} 
Artinya merokok adalah hal yang dapat membuat seseorang menjatuhkan dirinya sendiri dalam kebinasaan, karena rokok banyak mengandung zat-zat yang berbahaya. Sesungguhnya Allah SWT sangat menyayangi manusia yang berbuat baik dengan menjaga apa yang telah diberikanNya.

Rokok adalah "jajan” yang paling "nikmat” dan "murah”. Dikatakan nikmat karena orang yang biasa merokok sulit menghentikan kebisaannya. Kalau rokok tidak nikmat, ia pasti tidak menyukainya dan dengan mudah menghentikannya. Dikatakan nikmat karena bagi pecandunya, rokok memang mendatangkan perasaan nikmat, segar, tenang, fit, hilang rasa malas, pikiran terasa “jernih" (Partodiharjo, 2006, p. 34).

Disebut murah karena hanya dengan uang lima ratus rupiah, seseorang sudah dapat memperoleh sebatang rokok yang berisi 4 ribu macam zat kimia. Hanya melalui rokoklah anda dapat membeli 4 ribu macam zat kimia dengan harga Rp. 500. Sebab utama yang membuat remaja bisa mendapatkan rokok dengan mudah karena harga yang sangat terjangkau. Rokok merupakan tindakan menghambur-hamburkan uang untuk hal yang tidak bermanfaat.

Berikut firman Allah SWT yang menjelaskan bahwasanya merokok adalah pemborosan:

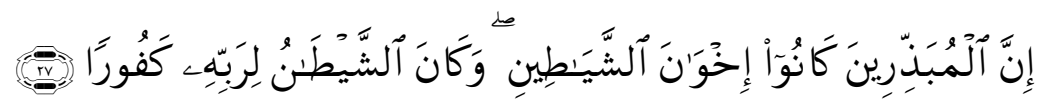

"Sesunggubnya pemboros-pemboros itu adalah saudara-saudara syaitan dan syaitan itu adalab sangat ingkar kepada Tuhannya.” (Q.S Al-Israa' 27)

Merokok merupakan tindakan mubabdzir (pemborosan) dan penyia-nyiaan terhadap harta. Mereka tidak mendapatkan apa-apa dari rokok kecuali ketenangan sesaat. Bahaya penyakit yang mengancam jiwa dan terbuangnya uang secara sia-sia.

Terdapat banyak alasan yang melatarbelakangi remaja untuk merokok. Merokok merupakan fungsi dari lingkungan dan individu. Artinya, perilaku merokok selain disebabkan dari faktor lingkungan juga disebabkan oleh faktor diri atau kepribadian.

Kemudian masalah-masalah yang dialami oleh individu seperti masalah keluarga, masalah sekolah, dan masalah-masalah lainnya semakin membuat individu semakin terdorong untuk mulai merokok. Remaja yang merasa kurang adanya perhatian yang ia dapatkan dari orang tua maupun orang disekitarnya. Dengan membuat masalah remaja bisa mendapatkan perhatian lebih dari orang terdekatnya termasuk dengan cara mengkonsumsi rokok. Dan juga rasa takut yang timbul dari teman sebaya yang memaksanya untuk merokok karena, apabila 
tidak merokok dikatakan tidak jantan atau banci. Faktor ejekan dari teman sebaya juga menimbulkan remaja untuk mencoba rokok.

Remaja mulai merokok berkaitan dengan adanya krisis aspek psikososial yang dialami pada masa perkembangannya yaitu masa ketika mencari jati diri. Dalam masa remaja ini sering terjadi ketidaksesuaian antara perkembangan psikis dan perkembangan sosial. Upaya-upaya untuk menemukan jati diri tersebut tidak selalu dapat berjalan sesuai dengan harapan masyarakat. Beberapa remaja melakukan perilaku merokok sebagai cara kompensatoris. Perilaku merokok bagi remaja merupakan perilaku simbolisasi. Simbol dari kematangan, kekuatan, kepemimpinan, dan daya tarik terhadap lawan jenis (Komasari \& Helmi, 2000). Perilaku merokok pada remaja juga akan semakin lama akan semakin meningkat sesuai dengan tahap perkembangannya yang ditandai dengan meningkatnya frekuensi dan intensitas merokoknya dan itu akan mengakibatkan mereka mengalami ketergantungan pada nikotin.

Namun, bagaimanapun latarbelakang remaja melakukan perilaku mengkonsumsi merokok tetap saja merokok sebagai salah satu bentuk adiksi yang harus dieliminir. Dalam hal ini remaja di sekolah merupakan subjek layanan profesi bimbingan konseling yang harus segera diberi bantuan. Kendatipun perilaku merokok pada remaja dilatarbelakangi lingkungan dan kepribadian, tetapi fokus bantuan konseling yang memandirikan adalah membantu individu untuk memiliki kepribadian sehat dan interdependen terhadap lingkungan.

Berdasarkan latar belakang masalah di atas dapat diidentifikasi beberapa masalah, yaitu: 1) ada sebagian siswa yang merokok di dalam sekolah; 2) ada sebagian siswa yang merokok untuk menghilangkan rasa emosionalnya; 3) ada sebagian siswa merokok yang mengakibatkan rasa takut yang mengancam dirinya; 4) ada sebagian siswa yang mengkonsumsi rokok karena mencari perhatian; 5) ada sebagian siswa yang belum mengetahui dampak negatif dari rokok; 6) ada sebagian siswa yang berfikir bahwa dengan rokok bisa membuatnya tenang; dan 7) ada sebagian siswa yang mempunyai rasa cemas atas perbuatan yang dilakukannya.

Melihat fenomena yang ada memang anak remaja yang banyak mengkonsumsi rokok dikarenakan ia ingin mencari jati diri tetapi dengan cara fikir yang berbeda. Masalah-masalah tersebut harus segera di atasi yakni dengan cara merubah pola pikir yang irrasional menjadi rasional untuk mengurangi kebiasaan merokok. Salah satu bantuan yang diberikan oleh guru pembimbing di sekolah adalah melalui terapi konseling Rational Emotive.

Menurut Willis (2009, p. 75), rational emotive ini memandang bahwa manusia adalah subjek yang sadar akan dirinya dan sadar akan objek-objek yang dihadapinya. Manusia adalah makhluk berbuat dan berkembang dan merupakan individu dalam satu kesatuan yang berarti, 
manusia bebas, berfikir, bernafsu dan berkehendak. Dalam hal ini dilihat remaja sadar dengan yang dilakukannya yaitu mengkonsumsi rokok yang menjadi kebiasaan.

Selanjutnya Willis (2009, p. 76) menjelaskan tujuan utama konseling rasional emotif di sini baik terhadap individu maupun terhadap kelompok adalah (1) memperbaiki dan mengubah sikap, persepsi, cara berfikir, keyakinan dan pandangan-pandangan yang irasional dan ilogis menjadi rasional dan logis agar klien dapat mengembangkan diri, meningkatkan aktualisasinya seoptimal mungkin melalui perilaku kognitif dan efektif yang positif, (2) Menghilangkan gangguan-gangguan emosional yang merusak diri sendiri, seperti: Rasa benci, rasa takut, rasa bersalah, rasa berdosa, rasa cemas, was-was, dan marah sebagai konsekuensi keyakinan yang keliru dengan jalan mengajar dan melatih klien untuk menghadapi hidup secara nasional dan membangkitkan kepercayaan, serta nilai-nilai kemampuan diri sendiri.

Berdasarkan penjelasan tersebut dapat dikatakan bahwa rational emotive mampu mengatasi persoalan-persoalan yang berkenaan dengan remaja, khususnya kebiasaan merokok. Kebiasaan merokok ini memang sangat mampu mengganggu emosional setiap orang, termasuk remaja. oleh karena itu, guru pembimbing atau konselor yang berwibawa akan mampu membantu siswa yang mengalami gangguan emosional untuk mengarahkan secara langsung pada para siswa yang memiliki pola pikir yang tidak rasional, serta mempengaruhi cara berpikir mereka yang tidak rasional untuk meninggalkan anggapan atau tanggapan yang keliru itu menjadi rasional dan logis (Sukardi, 2008, p. 152).

Adapun rumusan masalah dalam penelitian ini antara lain: 1) bagaimana kebiasaan merokok siswa sebelum pemberian terapi Rational Emotive?; 2) bagaimana kebiasaan merokok siswa sesudah pemberian terapi Rational Emotive?; dan 3) bagaimana efektivitas terapi konseling Rational Emotive dalam mengurangi kebiasaan merokok siswa?.

\section{METODOLOGI}

Metode dalam penelitian ini menggunakan eksperimen desain one group pre-test dan postest/pola sebelum dan sesudah dengan struktur (Arikunto, 2006, p. 85). Populasi dalam penelitian ini adalah seluruh siswa kelas X SMAN 3 Pekanbaru yang mempunyai kebiasaan merokok yang berjumlah 32 siswa. Untuk menentukan sampel penelitian ini maka peneliti menggunakan teknik purposive sampling/sampling bertujuan. Teknik ini dipandang lebih efektif dan efisien, di mana teknik ini merupakan teknik pengambilan sampel yang didasarkan atas adanya tujuan tertentu. Pengambilan sampel dengan cara ini dengan pertimbangan dan tujuan tertentu, yaitu siswa yang mempunyai kebiasaan merokok yang tinggi di banding siswa lain. Dalam hal ini peneliti memberikan pre test kepada kelas X SMAN 3 Pekanbaru yang sudah 
diketahui mempunyai kebiasaan merokok. Melalui teknik tersebut selanjutnya digunakan 5 siswa sebagai sampel penelitian. Untuk menjaring data tentang efektivitas terapi konseling rational emotive dalam mengurangi kebiasaan merokok, penulis menggunakan skala likert dengan empat alternatif jawaban yaitu: sangat setuju, setuju, tidak setuju, sangat tidak setuju. Selanjutnya instrument yang telah disusun dilakukan uji validitas dan reliabilitas. Teknik analisis data yang digunakan dalam penelitian ini adalah tes " $\mathrm{t}$ " untuk sampel kecil dari 30 yang berkorelasi. Karena sampel yang di ambil kurang dari $<30$ maka di gunakan Tes " $\mathrm{t}$ " untuk sampel kecil yang berkorelasi

\section{TEMUAN}

\section{Hasil Penelitian}

Berikut ini penulis paparkan rata-rata skor dan rata-rata persen angket kebiasaan merokok siswa sebelum dilakukan terapi konseling rational emotive yang digunakan untuk menentukan kategori/klasifikasi pada tinggi, sedang, dan rendah :

\section{Tabel Skor dan Rata-rata Angket Kebiasaan Merokok Siswa}

\begin{tabular}{ccc}
\hline Responden & Sebelum & Persentase $(\%)$ \\
\hline A & 94 & $78,333 \%$ \\
\hline B & 90 & $75 \%$ \\
\hline C & 93 & $77,5 \%$ \\
\hline $\mathrm{D}$ & 94 & $78,333 \%$ \\
\hline $\mathrm{E}$ & 92 & $76,667 \%$ \\
\hline $\mathrm{N}=5$ & 463 & 385,833 \\
\hline Mean & 92,6 & $77,167 \%$ \\
\hline
\end{tabular}

Berdasarkan tabel di atas diketahui bahwa skor total siswa sebelum diberikan terapi konseling rational emotive sebesar 463. Dengan berpedoman pada norma kategorisasi yang telah dipaparkan sebelumnya, maka siswa dikategorikan memiliki kebiasaan merokok yang tinggi dengan nilai rata-rata skor sebesar 92,6 dan rata-rata persentase sebesar 77,167\%.

Berikutnya akan dipaparkan hasil rekapitulasi frekuensi dan persentase kebiasaan merokok siswa sebelum diberikan terapi rational emotive berdasarkan kategori tinggi, sedang, dan rendah :

\section{Tabel Hasil Rekapitulasi Frekuensi dan Persentase Kebiasaan Merokok Siswa}

\begin{tabular}{|c|c|c|}
\hline Kategori & Frekuensi & Persentasi \\
\hline Tinggi & 5 & $100 \%$ \\
\hline Sedang & 0 & $0 \%$ \\
\hline Rendah & 0 & $0 \%$ \\
\hline \multicolumn{2}{|c|}{ Total } & $100 \%$ \\
\hline
\end{tabular}


Berdasarkan tabel di atas dapat diketahui bahwa kebiasaan merokok siswa berada pada kategori tinggi dengan persentase sebesar 100\%, pada kategori sedang dengan persentase sebesar $0 \%$ dan pada kategori rendah dengan persentase sebesar $0 \%$.

Berikut ini penulis paparkan rata-rata skor dan rata-rata persen angket kebiasaan merokok siswa sesudah dilakukan terapi rational emotive yang digunakan untuk menentukan kategori/klasifikasi pada tinggi, sedang, dan rendah :

Tabel Hasil rekapitulasi angket kebiasaan merokok siswa

\begin{tabular}{ccc}
\hline Responden & Sesudah & Persentase (\%) \\
\hline A & 75 & $62,5 \%$ \\
\hline B & 80 & $66,667 \%$ \\
\hline C & 57 & $47,5 \%$ \\
\hline D & 54 & $45 \%$ \\
\hline E & 68 & $56,667 \%$ \\
\hline N $=5$ & 334 & 278,333 \\
\hline Mean & 66,8 & $55,667 \%$ \\
\hline
\end{tabular}

Berdasarkan di atas diketahui bahwa skor total siswa sesudah diberikan terapi rational emotive sebesar 334. Dengan berpedoman pada norma kategorisasi yang telah dipaparkan sebelumnya, maka siswa dikategorikan memiliki kebiasaan merokok yang sedang dengan nilai rata-rata skor sebesar 66,8 dan rata-rata persentase sebesar 55,667\%.

Berikutnya akan dipaparkan hasil rekapitulasi frekuensi dan persentase kebiasaan merokok siswa setelah diberikan terapi rational emotive berdasarkan kategori tinggi, sedang, dan rendah :

Tabel Hasil Rekapitulasi Angket Kebiasaan Merokok Siswa

\begin{tabular}{|c|c|c|}
\hline Kategori & Frekuensi & Persentase \\
\hline Tinggi & 0 & $0 \%$ \\
\hline Sedang & 3 & $60 \%$ \\
\hline Rendah & 2 & $40 \%$ \\
\hline \multicolumn{2}{|c|}{ Total } & $100 \%$ \\
\hline
\end{tabular}

Berdasarkan tabel di atas dapat diketahui bahwa kebiasaan merokok siswa berada pada kategori tinggi dengan persentase sebesar $0 \%$, pada kategori sedang dengan persentase sebesar 60\% dan pada kategori rendah dengan persentase sebesar $40 \%$.

Langkah selanjutnya adalah menghitung nilai "t" perbedaan kebiasaan merokok sebelum dan setelah diberikan terapi rational emotive. Setelah diperoleh harga $t_{0}$, maka selanjutnya adalah memberi interpretasi terhadap $\mathrm{t}_{0}$ dengan mencari $\mathrm{df}=5-1=4$, kemudian dikonsultasikan pada nilai " $\mathrm{t}$ " pada taraf signifikan 5\% (2,78). Dari hasil perhitungan diperoleh nilai $\mathrm{t}_{0}=4.691$ dan $\mathrm{t}_{\text {tabel }}=2,78$, maka nilai $\mathrm{t}_{0}>\mathrm{t}_{\text {tabel }}$. Berdasarkan hasil tersebut maka terdapat 
perbedaan yang signifikan antara kebiasaan merokok siswa sebelum dan sesudah diberi terapi konseling rational emotive.

\section{Pembahasan}

Merokok merupakan overt behavior di mana perokok menghisap gulungan tembakau. Merokok adalah menghisap gulungan tembakau yang dibungkus dengan kertas merokok sebagai menghisap rokok, dan rokok didefinisikan sebagai gulungan tembakau yang berbalut daun nipah atau kertas. merokok sebagai overt behavior karena merokok merupakan perilaku yang nampak. Sebagai overt behavior merokok merupakan perilaku yang dapat terlihat karena ketika merokok individu melakukan suatu kegiatan yang nampak yaitu menghisap asap rokok yang dibakar ke dalam tubuh, merokok adalah menghisap asap tembakau yang dibakar ke dalam tubuh dan menghembuskannya kembali keluar.

Seperti halnya perilaku lain, perilaku merokok pun muncul karena adanya faktor internal (faktor biologis dan faktor psikologis, seperti perilaku merokok dilakukan untuk mengurangi stres) dan faktor eksternal (faktor lingkungan sosial, seperti terpengaruh oleh teman sebaya). Perilaku merokok adalah aktivitas menghisap atau menghirup asap rokok dengan menggunakan pipa atau rokok (Sari, Ramdani, \& Eliza, 2003). Rokok juga mengandung nikotin yang sangat berbahaya bagi tubuh manusia.

Saat pertama kali mengonsumsi rokok, gejala-gejala yang mungkin terjadi adalah batukbatuk, lidah terasa getir, dan perut mual. Namun demikian, sebagian dari para pemula tersebut mengabaikan perasaan tersebut, biasanya berlanjut menjadi kebiasaan, dan akhirnya menjadi ketergantungan. Ketergantungan ini dipersepsikan sebagai kenikmatan yang memberikan kepuasan psikologis.

Perilaku merokok juga seringkali digunakan sebagai cara untuk mengatasi stres meskipun merokok bukanlah cara coping yang sehat atau menguntungkan. Menurut Sujadi, Yusuf \& Marjohan (2016) apabila siswa menghadapi situasi stres, seharusnya mereka mengambil tindakan yang diarahkan untuk merubah atau mengelola situasi yang penuh stres, bukan menjauh dari permasalahan tersebut, apalagi melakukan perbuatan yang tidak berguna.

Berdasarkan pengujian hipotesis yang peneliti lakukan, ditemukan hasil bahwa konseling individu dengan pendekatan rational emotive efektif untuk mengurangi kebiasaan merokok. Temuan ini mendukung beberapa penelitian terdahulu. Amirullah \& Sugiyo (2015) mengemukakan melalui penelitiannya bahwa kebiasaan merokok dapat diturunkan dari tinggi menjadi rendah melalui penerapan konseling melalui pendekatan rational emotive behavior therapy dengan teknik time projection. Nik (2013) menjelaskan bahwa Rational Emotional Behavior 
Therapy (REBT) efektif mengurangi perilaku merokok pada wanita yang tidak subur. Aggarwal (2014) juga berpendapat bahwa REBT yang ditemukan oleh Ellis dapat mengurangi kebiasaan merokok pada remaja. Sulistyoningrum (2018) melakukan Penelitian Tindakan Kelas Bimbingan dan Konseling (PTK-BK) terhadap siswa kelas IX-C SMP Negeri 5 Kota Tangerang dengan fokus upaya mengurangi kebiasaan merokok melalui pendekatan REBT, dengan hasil bahwa intervensi yang dilakukan efektif untuk mengurangi kebiasaan merokok pada siswa.

Berdasarkan hasil penelitian yang telah diuraikan, maka dapat diketahui bahwa kegiatan terapi konseling rational emotive sangat besar manfaatnya bagi siswa untuk mengurangi kebiasaan merokok. Oleh sebab itu, kepada guru BK diharapkan untuk terus meningkatkan pelaksanaan terapi konseling rational emotive khususnya untuk mengurangi kebiasaan merokok siswa. Selanjutnya kepada pihak sekolah diharapkan kiranya tetap dapat mendukung setiap program dan pelaksanaan layanan BK, khususnya yang berkenaan dengan mengurangi kebiasaan merokok siswa dan dapat menyediakan sarana, prasarana dan waktu yang cukup agar pelaksanaan terapi konseling rational emotive dapat terlaksana secara efektif.

\section{PENUTUP}

Dari hasil penelitian dan pembahasan yang telah dikemukakan pada halaman-halaman sebelumnya maka dapat diambil kesimpulan sebagai berikut:

1. Kebiasaan merokok siswa sebelum diberi terapi konseling rational emotive berada pada kategori tinggi dengan rata-rata skor sebesar 92,6 dan rata-rata persentase sebesar $77,167 \%$.

2. Kebiasaan merokok siswa setelah diberi terapi konseling rational emotive mengalami penurunan yakni berada pada kategori sedang dengan rata-rata skor sebesar 66,8 dan rata-rata persentase sebesar 55,667\%.

3. Terdapat perbedaan yang signifikan antara kebiasaan merokok siswa sebelum dan sudah diberi terapi konseling rational emotive yaitu sebesar 4.691. Artinya terapi konseling rational emotive efektif untuk mengurangi kebiasaan merokok siswa. 


\section{REFERENSI}

Aggarwal, Ishita. (2014). Albert Ellis' Theory of Personality and Its Influence on Youth Smoking: A Critical Review. Canadian Young Scientist Journal: 43-50.

Amirullah, Ganang Bachtiar \& Sugiyo. (2016). Mengurangi Perilaku Merokok Melalui Pendekatan REBT Dengan Teknik Time Projection. Indonesian Journal of Guidance and Counseling: Theory and Application, 5 (3): 7-11.

Desmita. (2010). Psikologi Perkembangan. Bandung: Remaja Rosdakarya.

Helmi, Avin Fadilla \& Komasari, Dian. (2000). Faktor-Faktor Penyebab Perilaku Merokok pada Remaja. Jurnal Psikologi, No. 1: 37-47.

Nik, Maryam Mousavi. (2013). Rational emotive behavior therapy (REBT) for depression and smoking cessation in infertile women. 2nd International Conference and Exbibition on Addiction Research \& Therapy ,July 22-24, 2013 Embassy Suites Las Vegas, NV, USA.

Partodiharjo, Subagyo. (2006). Kenali Narkoba dan Musubi Penyalahgunaannya. Erlangga: Jakarta.

Saktyowati, Dian Oky. (2008). Bahaya Rokok. Depok: Arya Duta.

Sari, Ari Tris Ochtia., Ramdhani, Neila., \&Eliza, Mira. (2003). Empati dan Perilaku Merokok di Tempat Umum. Jurnal Psikologi, No. 2: 81 - 90.

Sujadi, Eko., Yusuf, A. Muri., \& Marjohan. (2016). Hubungan antara Locus of Control dan Efektivitas Komunikasi antar Pribadi dengan Problem Focused Coping. Konselor, 5 (1), 24-32.

Sukardi, Dewa Kentut. (2008). Pengantar Pelaksanaan Program Bimbingan dan Konseling di Sekolah. PT. Rineka Cipta: Jakarta.

Sulistyoningrum, Nunuk Yuli. (2018). Mengurangi Perilaku Merokok pada Siswa Melalui Layanan Bimbingan Kelompok. Jurnal Penelitian Bimbingan dan Konseling, 3 (1): 98-108.

Willis, Sofyan S. (2009). Konseling Individual Teori dan Praktek. Bandung: Alfabeta. 